九州大学学術情報リポジトリ

Kyushu University Institutional Repository

\title{
A second look at the ants of the Camponotus herculeanus group in Eastern Asia
}

Yasumatsu, Keizo

Entomological Laboratory, Department of Agriculture, Kyushu University

Brown Jr. William Louis

The Museum of Comparative Zoology, Department of Entmology, Harvard University

https://doi.org/10.5109/22673

出版情報：九州大学大学院農学研究院紀要. 11 (1)，pp.45-51，1957-08. Kyushu University バージョン：

権利関係 : 
Journal of the Faculty of Agriculture, Kyūsh̄̄ University, Vol. 11, No. 1

August 30, 1957

\section{A second look at the ants of the Camponotus herculeanus group in Eastern Asia}

Keizô Yasumatsu and William L. Brown, JR.

Only six years ago, we reviewed the Palaearctic members of the Camponotus herculeanus group, with special reference to the forms of eastern Asia (Yasumatsu and Brown, 1951). The most important taxonomic decisions then reached concerned the groups herculeanusjaponicus and obscuripes-hemichlaena. We decided that $C$. japonicus G. Mayr was a temperate Asian race of the boreal $C$. herculeanus (Linnaeus), and that hemichlaena Yasumatsu et Brown was a south Japanese race of $C$. obscuripes G. Mayr, following the concepts of population systematics as summarized by E. Mayr (1942).

Within two years, however, the concept of subspecies as applied to animal systematics came into serious question (Wilson and Brown, 1953), so that a reappraisal of the $C$. herculeanus allies in eastern Asia was clearly called for. Such a reappraisal became possible under unusually favorable circumstances when, in 1956, Yasumatsu was able to visit the United States under the auspices of the Ministry of Education of the Japanese Government and had the opportunity to discuss the situation with Brown directly for the first time. At this meeting, we both had a chance to examine and consider additional information and material bearing on the herculeanus-complex problem, and as a result, we are able to offer a new interpretation that we believe to be more accurately representative of the natural relationships of the forms concerned.

\section{A.-C. herculeanus, japonicus and atrox}

In our 1951 paper, we offered evidence for the conspecificity of japonicus and herculeanus. This evidence consisted largely of the 
demonstration that intergradient forms existed in a broad zone running through northern China, Manchuria and neighboring lands, as well as in the high mountains of Japan, Korea and China. Putative intergrades were in our material nothing like so abundant as "pure" herculeanus and japonicus, a fact that makes it now possible, at least for the sake of argument, again to consider the two "extreme" forms as separate species. However, if we are to make such a separation more than a point of rhetoric, the samples we formerly called intergrades must be explained.

The japonicus extreme differs from the herculeanus extreme as follows.

\section{japonicus}

Color normally black overall, though head of major worker may be more or less dark red. Sculpture coarse, especially of gaster, dense, opaque. Median lobe of clypeus advanced distinctly beyond lateral lobes. Gastric pubescence long, coarse, abundant.

\section{herculeanus (E. Asia)}

Color normally black, with more or less red on alitrunk and legs. Sculpture fine, gastric dorsum more shining. Median lobe of clypeus approximately even with lateral lobes. Gastric pubescence short, usually not surpassing the posterior segmental borders.

As already mentioned above and in our 1951 paper, the great majority of available eastern Asian samples can be determined unequivocally as either japonicus or herculeanus on the basis of the characters cited. There may also be a difference in head shape, but the analysis of this character would require the measurement of a great many specimens, including the largest sizes of workers, which we do not have in sufficient numbers from the herculeanus (northern) part of the range. In 1951, we felt that the "intergrades," found mostly at low altitudes, indicated a zone of secondary intergradation between two subspecies. We know now that the intergrade samples (workers and females) we have actually seen do not form a continuum, but instead seem to fall into three classes. These classes exclude characterizations from the literature, to which we unconsciously gave too much weight in 1951.

Class $I$.

North Chinese and Manchurian specimens, essentially japonicus, but often with the clypeal lobe slightly less noticeably projecting and with gastric pubescence a bit more dilute, as compared to Japanese examples. Larger workers sometimes have the head more or less reddish in color, in life as well as in dried Museum specimens. This is the form Emery described as var. aterrima; specimens in the $\mathrm{MCZ}$ from the southern Urals ("var. saxatilis" Ruzsky) agree well wịth north Chinese 
"aterrima." Sculpture, pubescence and color are clearly very close to those of japonicus, and there is no convincing, direct evidence known to us to suggest that samples of this class occur at the same cxact sites with, and there grade into, any more herculeanus-like class. Variation in projection of the clypeal lobe is a character most difficult to evaluate, since it is slight at best, and since it is allometrically controlled in the very size-variable worker-female castes of this complex. It seems that the character is not especially well correlated with density of pubescence or any other feature, and it is not even possible to be sure that specimens from Japan have a more strongly projecting lobe on the average than, say, samples from northwestern China.

It is our opinion now that Class I belongs to $C$. japonicus, and that it is in fact not far from typical for this species. The most conspicuous variate, gastric pubescence, seems to show slight reduction in peripheral areas (i.e., those away from Japan and central China), and not just in the direction of herculeanus-inhabited areas. In fact, samples of both species from Sikang Province (at different altitudes) are sharply distinct. The mountains of sikang form the western scarp of the Tibetan Plateau, here rising sharply from the Red Basin of Szechuan. The japonicus samples from this general area of west-central China collected by D. C. Graham and by Brown show no tendency to vary toward herculeanus despite the proximity of the latter species here.

So far as can be determined from the many explicit records known to us, $C$. japonicus, including Class I samples, is always a soil nester in eastern Asia. The exact geographical range in full remains to be worked out. In addition to the Volga-Urals populations, there are presumably solid rccords such as that of Eidmann (1942), who noted C. japonicus from $2700 \mathrm{~m}$. at Turbaling, N. W. Himalaya, taken by the Nanga Parbat Expedition. The Siberian records, mostly in Russian publications, are of little use to us, due to their generally obvious taxonomic and nomenclatorial confusion in dealing with this complex. Actually, we have little reliable and explicit information about the northward extent of the $C$. japonicus distribution, where it is sympatric with C. herculeanus, if anywhere, and how it behaves toward the latter if the two are in direct contact.

\section{Class II.}

Samples falling in this class are now considered by us to represent probable melanic examples of $C$. herculcanus. They agree with herculeanus in all characters except their color, which is nearly or completely black throughout. A sample from the Southern Japanese Alps contains some workers with the alitrunk entirely black, but others 
with the extreme posterior part of the alitrunk red; these last examples are very similar to many Canadian and Alaskan samples in color as well as in other respects.

Apparently, the sachalinensis of Forel and some later authors is this melanic herculeanus form. Other melanic herculeanus populations are known from Italy and the western United States (see below). The black herculeanus samples can be distinguished from japonicus by sculpture, much less well developed pubescence, and by the short clypeal lobe. No intergradation to japonicus is known, despite intensive collecting in the mountains of Japan. It seems clear to us now that our category of the 1951 paper (p. 36): “japonicus...(b) Black intergrades to herculeanus" wrongly includes the present Classes I and II without distinction. Actually, these two classes seem to be examples of color convergence, not intergradation. Without seeing types, it is impossible to be sure whether varieties jalutica, sachalinensis and manczshurica belong to Class III, to mixtures of Classes $\bar{I}$ and $I I$, or to something completely different from anything we have seen.

\section{Class III.}

This is equivalent to our 1951 japonicus category "(c) Intergrades to herculeanus with red alitrunk" (pp. 37-38). The prior name, which we shail appiy here, is atrox Emery. The few specimens actualiy available to us are samples of a single nest series from Mt. Kongo in central Korea, from a single depauperate nest taken in Shansi Province by Yasumatsu, and a single major worker from "Eastern Tomh," presumably near Peking, in the MCZ Collection. These specinens have the sculpture and pilosity of jatponirus, but the alitrunk is red, not black. The clypeus, for what this character is worth, seems to be intermediate between those of "typical" japonicus and herculeanus.

Yasumatsu found only the single small nest in Shansi, although he found a great many nests of japonicus during his collecting in this province. In neighboring Shensi Province, despite extensive collecting, Brown found only japonicus at Hanchung, Pao Cheng, Miao Tai Tze in the Tsinling Range, and on the Wei River Plain, and never saw atrox, either in this province or elsewhere in western and north-western China. Other published records referring to this form are from northern Korea and from Jehol. It seems reasonably clear that such a large ant, conspicuous by virtue of its color, must be rather uncommon and sporadic in China, Korea and Manchuria, at least, to have yielded so few and scattered records. That atrox is not known from the Japanese highlands, despite intensive collecting, is significant, especially when one considers that such experienced ant collectors as Yano, Teranishi, Yoshioka, Morishita, Silvestri, Okamoto and others have worked this area over a long period. 
From our present knowledge, the true status of atrox is impossible to determine with any finality. Three possibilities seem worth considering.

(1) Atrox may be a northern or upland variant of japonicus. This has against it the apparent intermediate nature of the clypeus, if this character may be trusted. Also, atrox has not been found in Japan, although japonicus is of course abundant there. Where it occurs, atrox is apparently within the range of japonicus, so that the differences, if they are genetically controlled, would have to be under simple, all-or-none genetic control if applying to one and the same species.

(2) Atrox may be the result of occasional hybridization between japonicus and herculeanus. This possibility would be worth more consideration if the second putative parent, herculeanus, had ever been found unequivocally associated at even a single locality with japonicus and atrox. There appear to be no safe records of the three forms from any one locality. If hydridization occurs, one would except it to affect not only color, but also sculpture and pubescence, in the same areas where atrox was found; there exists no evidence to this effect. The lack of atrox in Japan does not mean too much, because there even the herculeanus are nearly or quite completely black.

(3) Possibly atrox is a species apart from both japonicus and herculeanus. If this is the case, atrox might represent the remnants of the parent stock (from which japonicus diverged), now caught between japonicus, expanding from the south, and herculeanus, occupying the far north. This third possibility may be the best one we can entertain for the time being, and so long as atrox seems to have a fair chance of being a good species, it will be best to recognize Camponotus atrox Emery (NEW STATUS) as a provisional full species.

The new cxamination of the japonicus-herculeanus "intergrades" shows that most of these forms can be placed to one or the other of the two specics, and that they are probably not the result of interbreeding. At most, one could claim a limited amount of hybridization to account for some of these variants, but the availability of aiternative explanations makes even this moderate hypothesis seem rather superfluous. At any rate, there is no good reason to continue to consider japonicus a "subspecies" of herculeanus; instead, we return to the original concept of Gustav Mayr, who described Camponotus japonicus as a good species. The certain synonyms of $C$. japonicus at this writing are: aterrima Emery, saxatilis Ruzsky, sanguinea Karawajew, miltotus Wheeler and wui Wheeler. Forms of uncertain affinities, but probably belonging to $C$. herculeanus, are: jakutica Karawajew, sachalinensis Forel, and manczshurica Ruzsky. 
We urgently need to have a much clearer picture of the range and variation of $C$. herculeanus in central Asia and Siberia. The European herculeanus usually have all-red alitrunks, and when, as in the southern montane populations ("var. nadigi"), the alitrunk turns black, it does so in a rather even way, through increased melanization of the entire tagma. The American and Japanese samples, on the other hand, show more progressive melanization from front to rear; e.g., the propodeum alone may remain red, while the promesonotum is entirely black. Do both these tendencies exist in eastern Siberian populations, and if so, what happens where they merge or meet?

Another question surrounds the identity of the " $C$. herculeanus eudokiae" of Ruzsky, even the description of which remains unavailable to use. And then we have a nest series (MCZ) from Pskem, in the western Tien Shan, at an altitude of about $1000 \mathrm{~m}$., with all-red alitrunk and other general features of herculeanus, but with the appressed gastric pubescence longer than usual, surpassing the posterior borders of the segments. Elsewhere, pubescence of similar, and even more extreme, development is found in the southern herculeanus populations of western North America ("race modoc"). We hope these problems have attracted or will attract the attention of Russian ant specialists.

\section{C. obscuripes and hemichlaend}

We described hemichlaena in 1951 as a provisional southern race of $C$. obscuripes, but additional information now available leads us to separate these two as good species, so that the former now is considered as Camponotus hemichlaena Yasumatsu et Brown (NEW STATUS). C. hemichlaena has a characteristic black prothorax, contrasting sharply with reddish color of the rest of the alitrunk. The species is widely distributed in Kyushu, Shikoku and southern Honshu. Many collections and observations made in these areas now agree in showing that obscuripes and hemichlaena frequently occur in the same or closely adjacent localities, but without producing intergrades.

We had already reported in 1951 that obscuripes occurs rarely at high altitudes in Kyushu. Now we find that both species occur in the same districts of eastern Shikoku. Generally speaking, obscuripes tends to occupy the higher altitudes, but altitudinal separation is not complete. Samples from Honshu indicate that the situation is much the same there in the southern part of the island; no intermediates are yet known from any of these areas. All colony series so far seen are "pure," either obscuripes or hemichlaena, never both. There are some indications of direct struggle between the two in eastern Shikoku, but their bionomics and competitive status have not yet been studied in any detail. 
The circumstances suggest that hemichlaena is a southern derivative from the obscuripes stock that is now slowly replacing the latter from south to north and from lower to higher altitudes. The possibility is even more interesting when one considers that $C$. japonicus may be advancing northward against $C$. herculeanus in Asia, while the same may be true of $C$. pennsylvanicus De Geer vs. C. herculeanus in the eastern part of North America (Brown and Wilson, unpublished data). Conclusive demonstration of such northward expansion of warmzone against cold-zone species would only be following the principles laid down in the zoogeographic writings of P. J. Darlington (1948 and in press).

\section{REFERENCES}

Darlington, P. J. 1948. The geographical distribution of cold-blooded vertebrates. Quart. Rev. Biol., 23: 1-26, 105-123.

Eidmann, H. 1942. Zur Kenntnis der Ameisenfauna des Nanga Parbat. Zool. Jahrb. Syst., 75: 239-266, cf. p. 250.

Mayr, E. 1942. Systematics and the origin of species. Columbia University Press, New York.

Wilson, E. O. and W. L. Brown. 1953. The subspecies concept and its taxonomic application. Syst. Zool., 2: 97-111.

Yasumatsu, K. and W. L. Brawn. 1951. Revisional notes on Camponotus herculeanus Linné and close relatives in Palearctic regions (Hymenoptera: Formicidae). Jour. Fac. Agric. Kyushu Univ., 10: 29-44. 